\title{
Organic pollutants in water and its remediation using biowaste activated carbon as greener adsorbent
}

\begin{abstract}
The occurrence of organic pollutants in water bodies has elevated in recent years causing serious damage to human health and aquatic ecosystems. Cost-effective, environmental friendly and renewable techniques therefore need to be employed for the treatment of wastewater before discharging into natural water bodies. Biomass material serves as a promising, ecofriendly, and economical resource for synthesis of versatile adsorbent such as activated carbon. Thus, the present manuscript gives a view about the removal of organic pollutant from wastewater by activated carbon synthesized from biomass.
\end{abstract}

Keywords: Organic pollutants, Biomass, Activated carbon
Volume I Issue 3 - 2017

\author{
Parimal Chandra Bhomick,Aola Supong, \\ Dipak Sinha \\ Department of Chemistry, Nagaland University, India
}

Correspondence: Dipak Sinha, Department of Chemistry, Nagaland University, India, Tel +9| 36922682 I5, Fax +9| 3692268248,Emaildipaksinha@gmail.com

Received: September 2I, 2017 | Published: October 10, 2017

\section{Opinion}

Water is a vital resource for sustaining life, however in present scenario the access to clean safe water around the world has become a burning concern especially in developing and emerging countries attributing to increase in population, climate change and environmental water pollution by sewages, industrial effluents, chemicals, domestic wastes, pesticides, pharmaceuticals and so on. These pollutants consist of organic, inorganic, biological and radioactive substances that make the water unfit for any use and poses a threat to human health, animals and plants as they are either toxic, carcinogenic or mutagenic. ${ }^{1-3}$ According to report of World Water Development 2017, currently only $20 \%$ of wastewater produced globally receives proper treatment while majority of it is discharged without any form of treatment into the environment. ${ }^{4}$ The occurrence of organic pollutants in wastewater have increased tremendously in modern years and has become a critical concern because of their toxicity, semi volatile nature, low water solubility, high bioaccumulation and non-biodegradability under normal environmental condition..$^{5-7}$ These types of organic pollutants such as phenolic compounds, polycyclic aromatic hydrocarbons (PAHs) and agricultural chemicals (organic pesticides and organic herbicides) have been considered as critical problems as it leads to aquatic system depletion, environmental degradation and also affect human health such as reproductive system disorders, endocrine disruption, obesity and cancer. ${ }^{8,9}$ In this regard, water purification have now become the main critical issue world-wide for which strict legislation has been formulated by World Health Organization for organic compounds for Drinking-Water Quality. ${ }^{10,11}$ Many ongoing studies in water purification remain a severe challenge to governments, scientists and industries, as lack of cost-effective water purification technology has aggravated the crisis of clean and safe water for the fast expanding population. Over the years, various methodologies to remediate these water threats have been developed, such as photocatalytic degradation, ${ }^{12}$ advanced oxidation, ${ }^{13}$ micellar enhanced ultra filtration, ${ }^{14}$ combined photo-fenton and ultrasound, advanced oxidation, aerobic degradation, adsorption, filtration, ozonation, coagulation, flocculation, distillation, extraction, precipitationetc. ${ }^{15}$
However, Adsorption has been found to be superior in terms of costeffectiveness, simplicity of design and ease of operation and has always evolved as a front line remediation for water purification. Selective adsorption utilizing biological materials, mineral oxides, activated carbons, or polymer resins have been widely documented as a potential method for removal of pollutants from water recently. ${ }^{16}$ Among all the adsorbents, activated carbon has been used extensively for remediation of various organic pollutants from wastewater. ${ }^{17,18} \mathrm{~A}$ wide variety of activated carbon has been synthesized from different biowaste materials such as olive stones, ${ }^{19}$ vermiculate plant, ${ }^{20}$ bamboo dust, coconut shell, groundnut shell, rice husk and straw, ${ }^{21}$ banana peel and pomegranate peel, ${ }^{22,23}$ Apricot Stone, ${ }^{24,25}$ rice husk, ${ }^{26}$ corn cob,,${ }^{27}$ etc. Activated carbon prepared from biomass apricot stone shells was found to remove of 2, 4-dinitrophenol with an adsorption capacity of $232 \mathrm{mg} / \mathrm{g} .{ }^{28}$ Monolayer adsorption of oxamyl with adsorption capacity of $147.05 \mathrm{mg} / \mathrm{g}$ was also studied using apricot stone activated carbon. ${ }^{24}$ Removal of phenol using ratten saw dust activated carbon and corn grain-based activated carbon was studied having adsorption capacity of $149.25 \mathrm{mg} / \mathrm{g}$ and $256 \mathrm{mg} / \mathrm{g}$ respectively also been reported. ${ }^{29,30}$ India being the second most populated country also experiences fresh water scarcity above all other challenges and it is estimated that about 38,254 million litres per day of wastewater is generated especially in urban areas and only $21 \%$ of it is treated and the rest of the untreated water accounts for the pollution of water with different kind of contaminants in addition to pollution created by natural sources. ${ }^{31-33}$ These issues could be addressed by converting the tons of biomass into wealth by production of cost-effective versatile adsorbent with high adsorption capacity, low energy requirement and high removal efficiency. As biomass is easily available, cheaper and renewable, there is a bigger scope of research forsynthesis of activated carbon as an adsorbent for removal of organic compounds from water.

\section{Conclusion}

In our view, more biomass material could be explored and utilize for preparation of inexpensive activated carbon over high cost commercial activated carbon which could further be used for efficient 
removal of organic pollutants as well as other contaminants from polluted water. Moreover, activated carbon prepared from biowaste material will prove as an economical, renewable and greener source of adsorbent for wastewater treatment.

\section{Acknowledgements}

The Authors Parimal Chandra Bhomick and Aola Supong are thankful to DST-INSPIRE Fellowship for financial assistance.

\section{Conflict of interest}

None.

\section{References}

1. Gonzalez S, Lopez Roldan R, Cortina JL. Presence and biological effects of emerging contaminants in Llobregat River basin: a review. Environmental Pollution. 2012;16:83-92.

2. Uner O, Gecge 1U, Bayrak Y. Adsorption of Methylene Blue by an Efficient Activated Carbon Prepared from Citrullus lanatus Rind: Kinetic, Isotherm, Thermodynamic, and Mechanism Analysis. Water Air \& Soil Pollut. 2016;227:247

3. Sarkar M, Rahman AKML, Bhoumik NC. Remediation of chromium and copper on water hyacinth (E crassipes) shoot powder. Water Resources and Industry. 2017;17:1-6.

4. WWAP (United Nations World Water Assessment Programme).The United Nations World Water Development Report 2017 Wastewater. UNESCO, France: The Untapped Resource; 2017. p. 1-198.

5. Abdeen Z, Mohammad SG. Study of the adsorption efficiency of an ecofriendly carbohydrate polymer for contaminated aqueous solution by organophosphorus pesticide. OJOPM. 2013;4(1):16-28.

6. Chen B, Yuan M, Liu H. Removal of polycyclic aromatic hydrocarbons from aqueous solution using plant residue materials as a biosorbent. Journal of Hazardous Materials. 2011;188(1-3):436-442.

7. Valili S, Siavalas G, Karapanagioti HK, et al. Phenanthrene removal from aqueous solutions using well-characterized, raw, chemically treated, and charred malt spent rootlets, a food industry by-product. $J$ Environ Manage. 2013;128:252-258.

8. Nanseu Njiki CP, Dedzo GK, Ngameni E. Study of the removal of paraquat from aqueous solution by biosorption onto Ayous (Triplochitonschleroxylon) sawdust. Journal of Hazardous Materials 2010;179(1-3):63-71.

9. Nagda GK, Diwan AM, Ghole VS. Potential of tendu leaf refuse for phenol removal in aqueous systems. Appl Ecol Environ Res. 2007;5(2):1-9.

10. World Health Organization. Guidelines for drinking-water quality, (4th edn). Switzerland: World Health Organization; 2011. p. 1-564.

11. Amin MT, Alazba AA, Manzoor U. A Review of Removal of Pollutants from Water/Wastewater Using Different Types of Nanomaterials. Adv mater scieng. 2014:1-24.

12. Sohrabi MR, Ghavami M. Photocatalytic degradation of Direct Red 23 dye using UV/TiO2: effect of operational parameters. J Hazard Mater. 2008;153(3):1235-1239

13. Gupta V. Application of low-cost adsorbents for dye removal-a review. $J$ Environ Manage. 2009;90(8):2313-42.

14. Zaghbani N, Hafiane A, Dhahbi M. Removal of Safranin T from wastewater using micellar enhanced ultrafiltration, Desalination. 2008;222(1-3):348-356

15. Ahmad T, Rafatullah M, Ghazali A, et al. Removal of pesticides from water and wastewater by different adsorbents: a review. J Environ Sci Health C. 2010;28(4):231-271.
16. Li YH, Liu FQ, Xia B, et al. Removal of copper from aqueous solution by carbon nanotube/calcium alginate composites. Journal of Hazardous Materials. 2010;177(1-3):876-880.

17. Cheremisinoff PN, Angelo CM. Carbon Adsorption Handbook, Ann Arbor Science Publishers Inc Ann Arbor MI; 1980;1-54.

18. Ata A, Nalcaci OO, Ovez B. Macro algae Gracilariaverrucosa as a biosorbent: a study of sorption mechanisms. Algal Res. 2012;1(2): 194-204.

19. El Bakouri H, Usero J, Morillo J, et al. Adsorptive features of acidtreated olive stones for drin pesticides: equilibrium, kinetic and thermodynamic modeling studies. Bioresource Technology. 2009;100(18):4147-4155.

20. Bestani B, Benderdouche N, Benstaali B, et al. Methylene blue and iodine adsorption onto an activated desert plant. Bioresour Technol. 2008;99(17):8441-8444.

21. Kannan N, Sundaram MM. Kinetics and mechanism of removal of methylene blue by adsorption on various carbons-a comparative study. Dyes and Pigments. 2001;51(1):25-40.

22. Soto ML, Moure A, Dominguez H, et al. Recovery concentration and purification of phenolic compounds by adsorption: a review. Journal of Food Engineering. 2011;105(1):1-27.

23. Achak M, Hafidi A, Ouazzani N, et al. Low cost biosorbent "banana peel" for the removal of phenolic compounds from olive mill wastewater: kinetic and equilibrium studies. J Hazard Mater. 2009;166(1):117-125.

24. Ahmed SM, Mohammad SG. Egyptian apricot stone (Prunusarmeniaca) as a low cost and eco-friendly biosorbent for oxamyl removal from aqueous solutions. American Journal of Experimental Agriculture. 2014;4(3):302-321.

25. Somaia G Mohammad. Biosorption of pesticide onto a low cost carbon produced from apricot stone (Prunusarmeniaca): equilibrium, kinetic and thermodynamic studies. Journal of Applied Sciences Research. 2014;9(10):6459-6469.

26. Akhtar M, Bhanger M I, Iqbal S, et al. Sorption potential of rice husk for the removal of 2,4-dichlorophenol from aqueous solutions: kinetic and thermodynamic investigations. J Hazard Mater. 2006;128(1):44-52.

27. Ara B, Shah J, Jan M R, et al. Removal of metribuzin herbicide from aqueous solution using corn cob. International Journal of Science, Environment. 2013;2(2):146-161.

28. Daifullah AAM, Girgis BS. Removal of some substituted phenols by activated carbon obtained from agricultural waste. Water Research 1998;32(4):1169-1177.

29. Hameed BH, Rahman AA. Removal of phenol from aqueous solutions by adsorption onto activated carbon prepared from biomass material. $J$ Hazard Mater. 2008;160(2-3):576-581.

30. Park KH, Balathanigaimani MS, Shim WG, et al. Adsorption characteristics of phenol on novel corn grain-based activated carbons. Microporous Mesoporous Mater. 2010;127(1-2):1-8.

31. Paul J, Mas E. The Emergence of China and India in the Global Market. Journal of East-West Business. 2016;22(1):28-50.

32. Lal K, Kaur R, Rosin KG, et al. Low-Cost Remediation and On-Farm Management Approaches for Safe Use of Wastewater in Agriculture. In: Dagar J, Sharma P, Sharma D, Singh A (Eds.), Innovative Saline Agriculture, Springer, India; 2016.p.265-275.

33. Anumol T, Vijayanandan A, Park M, et al. Occurrence and fate of emerging trace organic chemicals in wastewater plants in Chennai, India. Environment International. 2016;92(93):33-42. 